\title{
Geological conditions of karst development in the Nizhneirensko-Orda area (Perm Krai, Russia)
}

\author{
Eugene Erofeev, Valery Kataev
}

RF Perm State University (PSNIU), 614990, Perm, Russia

\begin{abstract}
The article presents the results of research on the use of remote sensing methods in combination with general geological methods to study the patterns of karst development. Practical aspects of expanding the possibilities of using remote sensing methods for engineering and geological surveys in territories of karst development are considered. Analysis and interpretation of the research materials were carried out using spatial analysis and mathematical methods. The priority tasks of the research were to evaluate and expand the possibilities of using remote methods as part of a complex of engineering and geological surveys, to combine remote research methods with general geological methods for solving specific practical problems, to establish general laws of the influence of various natural factors on the intensity and parameters of surface karst forms, their analysis and mathematical justification.
\end{abstract}

Introduction. Taking into account the regulatory requirements of SP 11-1057-II [1] for engineering and geological surveys in karst territories in terms of the integration of Earth remote sensing materials (aerial and cosmophotographs) with general geological research methods, the authors, based on the results of karstological interpretation, space radar surveying the earth's surface and drilling materials, a mathematical assessment of the influence of various natural factors on the parameters of surface karst forms is given.

Research area. The Nizhneirensko-Orda area, which occupies the right bank of the lower course of the Iren river up to the longitude of the village of Orda, corresponding to the northern part of the Irensky gypsum and carbonate-gypsum karst region, was chosen as the research area [2]. Administratively, it is the territory of Ordinsky and Kungursky municipal districts of Perm Krai.

Geological and structural conditions - platform, the site is located within the Veslyansky swell, complicating the Bym-Kungur depression. The geological section has been studied based on materials from structural exploration wells to depths of 200-400 m. The geological structure includes deposits of the Ufa $\left(\mathrm{P}_{1} \mathrm{u}\right)$, Kungurian $\left(\mathrm{P}_{1} \mathrm{~kg}\right)$, and Artinskian $\left(\mathrm{P}_{1}\right.$ ar) stages, covered loose eluvial-deluvial and alluvial sediments. The nature of the distribution of karst and cover deposits predetermined the conditions for the development of karst. Sulphate-carbonate deposits of the Irenian horizon $\left(\mathrm{P}_{1}\right.$ ir), to a lesser extent carbonate deposits of the Filippovsky horizon $\left(\mathrm{P}_{1} \mathrm{fl}\right)$ and Artinskian stage $\left(\mathrm{P}_{1}\right.$ ar) karst. In the eastern part, the Irene horizon has been destroyed to various depths and transformed into karst breccia (Q-N), represented by cemented anhydrite and dolomite fragments (Fig. 1).

Karst rock in watersheds are exposed or covered with turf, or stratified deposits of the Solikamsk horizon. In large areas in river valleys, karst rock are overlain by alluvial and eluvial deposits. Karst forms are very diverse: funnel, sinkholes, caves, karst ravine, ponors etc. [2].

Geological exploration. The territory of the site and adjacent areas is characterized by a high degree investigation. The research was based on materials from drilling, complex hydrogeological surveys, and special works on studying the karst of the Perm Krai territory.

Cartographic constructions are based on the materials of lithological and stratigraphic breakdowns of structural and prospecting (298 pieces) and various hydrogeological (450 pieces) wells that opened the top of the Irene horizon. The section was dissected according to GIS. Information on the surface karst content was obtained from the materials of the CFS interpretation [3-5]. The topographic base was built using space radar imagery (SRTM).

Geological exploration. The territory of the site and adjacent areas is characterized by a high degree investigation. The research was based on materials from drilling, complex hydrogeological surveys, and special works on studying the karst of the Perm Krai territory.

Cartographic constructions are based on the materials of lithological and stratigraphic breakdowns of structural and prospecting (298 pieces) and various hydrogeological (450 pieces) wells that opened the top of the Irene horizon. The section was dissected according to GIS. Information on the surface karst content was obtained from the materials of the CFS interpretation [3-5]. The topographic base was built using space radar imagery (SRTM).

The analysis was based on a set of elementary maps based on the materials of generalization and interpretation of the initial data. 


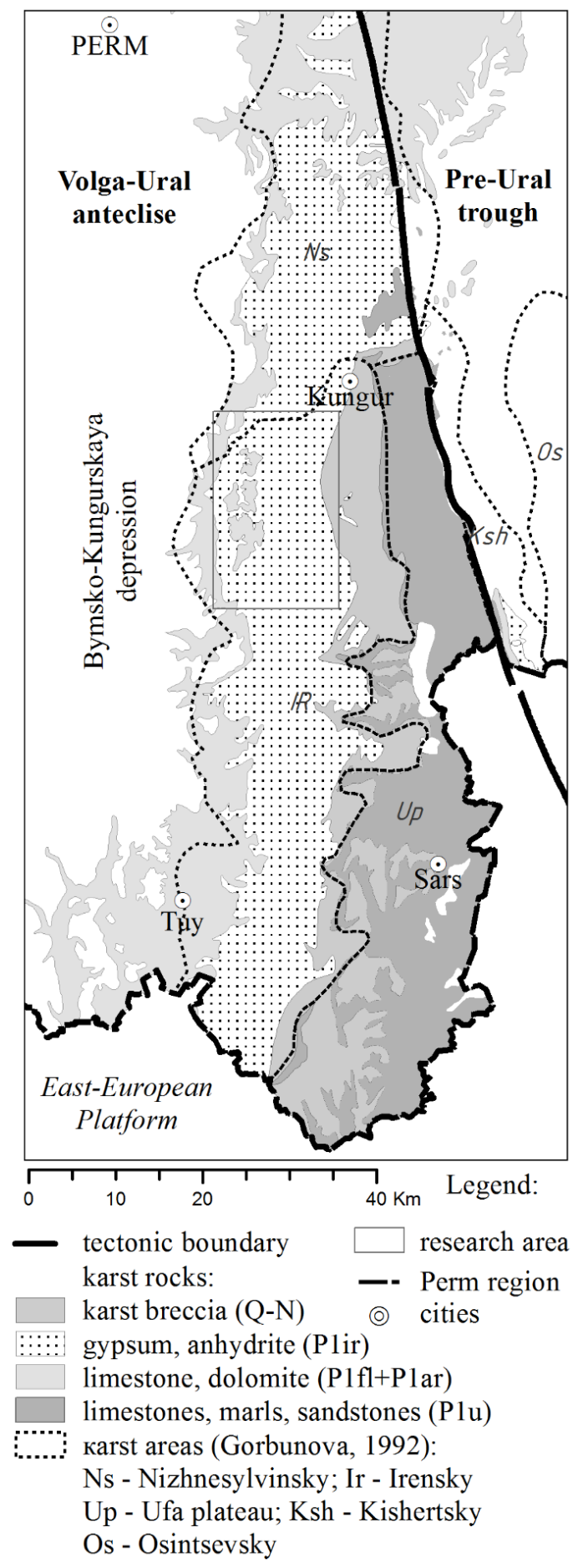

Fig. 1 Map of karst rocks of the Perm region

The methodological base that determines the approaches to the gradation of the identified factors and the sequence of mathematical calculations was the probabilistic-statistical theory of V.V. Tolmachev [6], some of the methodological provisions of which are discussed in detail in [7]. The processing of research results was carried out using the methods of mathematical methods. 
Spatial analysis is based on the following methodological principles: the probability of the formation of disrupted surface forms is controlled by the influence of numerous natural factors, where the role of each individual factor can manifest itself in the form of a certain tendency, which can be expressed quantitatively by a system of coupling coefficients Qi.

Gradation Qi $(-1 \ldots+1)$ reflects the probability of occurrence of failures: from -1 , the formation of failures with the i-th attribute of the factor under study is impossible, up to +1 , on the contrary, the occurrence of failure forms is possible only with the i-th attribute.

The ranking and assessment of the degree of influence of the selected natural factors on the intensity of the formation of karst sinkholes in general can be performed using the concept of entropy from information theory. The informational entropy $\mathrm{E}$ of the event $(\mathrm{x})$ is the sum (with a minus sign) of all the products of the relative frequencies of occurrence of the event $\mathrm{i}$, multiplied by their binary logarithms. Comparing the ratio of entropies (Emax / E) of several factors, one can determine the degree of their significance in relation to the influence of factors on the formation of sinkholes (surface karst forms) [6].

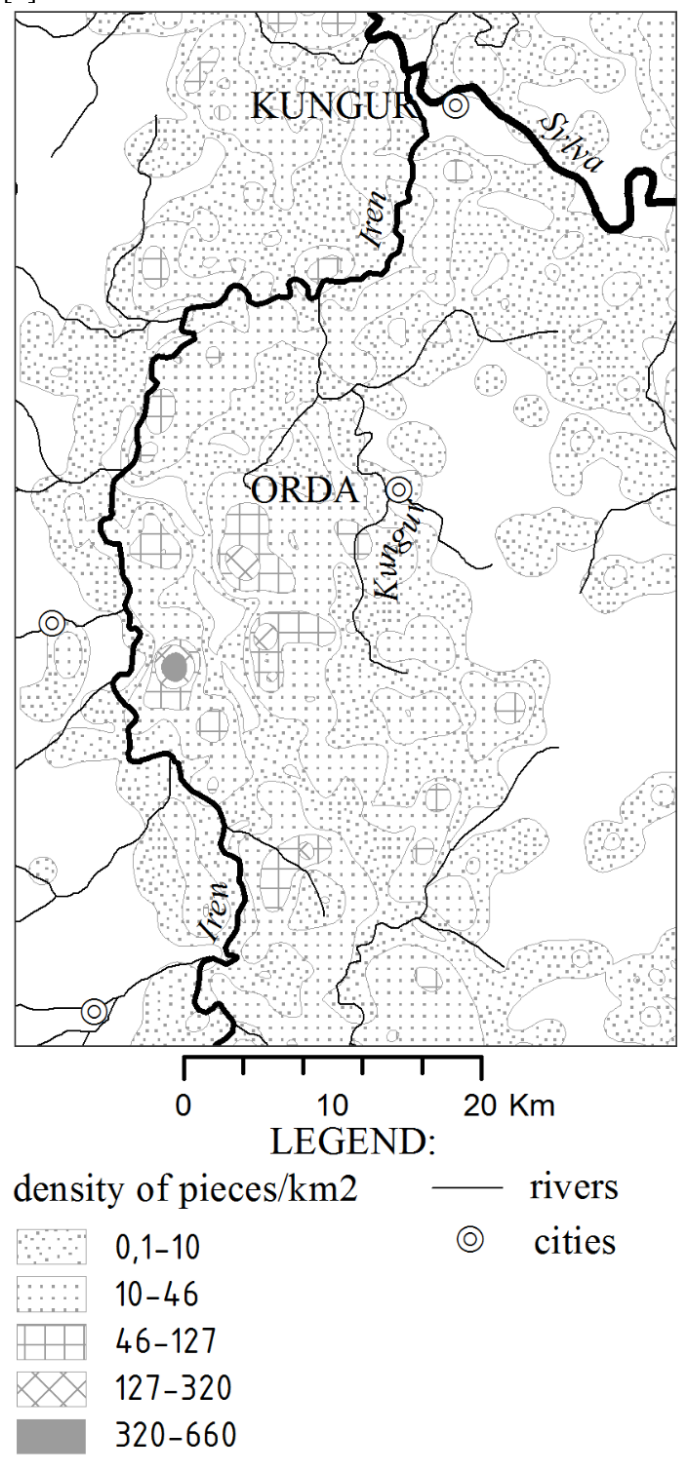

Fig. 2 Density map of karst forms

Research result. Almost 19 thousand forms were identified within the boundaries of the area, the cross-section size was set for 7384 pieces. The density of the karst forms varies from 0.1 to $660 \mathrm{units} / \mathrm{km} 2$ (Fig. 2). Spread of values is due to a combination of various geological factors.

The largest number of forms (10469 forms) corresponds to the area of development of the Lunezhka pack, 2039 forms - Tyuiskaya, 2432 - Demidkovskaya, 20 - Elkinsko-Shalashninskaya. A significant number of forms were also 
recorded within the distribution of the solikamsk cover deposits -2255 forms. The maximum density of the karst forms corresponds to the boundary between the Irenian and Solikamsk rocks, where the karst rocks are covered only by a thin cover of loose sediments. The most karst-covered are the slopes of river valleys and watersheds of the Iren and Kungur rivers, cut by a gully-girder network (Fig. 2).

This regularity is well traced by the nature of the decrease in the number of karst forms as these forms are removed from the main and smaller rivers. The analysis of remoteness shows that the erosion dissection of the relief (depth of incisions, density of the modern hydro network) is a localizing factor in the development of the karst process. As you move away from the drains, the number of forms decreases sharply (Fig. 3).

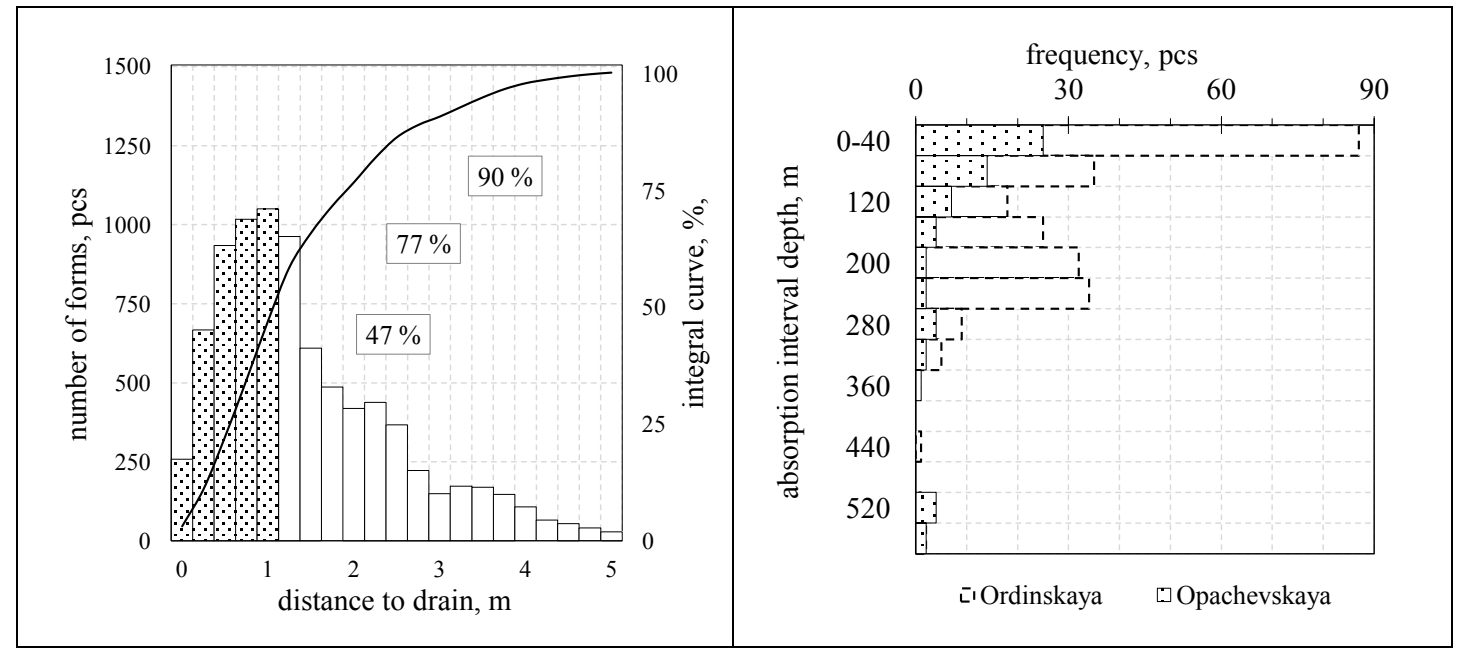

Fig. 3 Dependence of the number of karst forms on the distance from the river network

Fig. 4 Histogram of absorption depth distribution

Almost half (47\%) of all identified forms were localized within a narrow kilometer strip bounding the river network, and the remaining $53 \%$ were unevenly dispersed within a four-kilometer buffer zone. Also, a change in the diameters of the funnels is noted, for example, with distance from the drain, the average diameter increases from $15.9 \mathrm{~m}$ to $23.5 \mathrm{~m}$, and the maximum size from a distance of $2-2.5 \mathrm{~km}$ begins to slowly decrease from $90 \mathrm{~m}$ to $43 \mathrm{~m}$.

An idea of the nature of the location of underground karst cavities and fractured zones in depth is given by the mud loss diagram of the Orda and Opachevskaya areas (Fig. 3). The maximum number of losses corresponds to the intervals of occurrence of the Irenian horizon of $20-80 \mathrm{~m}$. At the depths corresponding to the Filippov horizon, their number sharply decreases and increases again after driving the top of the Artinskian stage.

The empirical distribution of the transverse dimensions of the karst sinkholes observed at the reference site corresponds to the logarithmically normal law (Fig. 5).

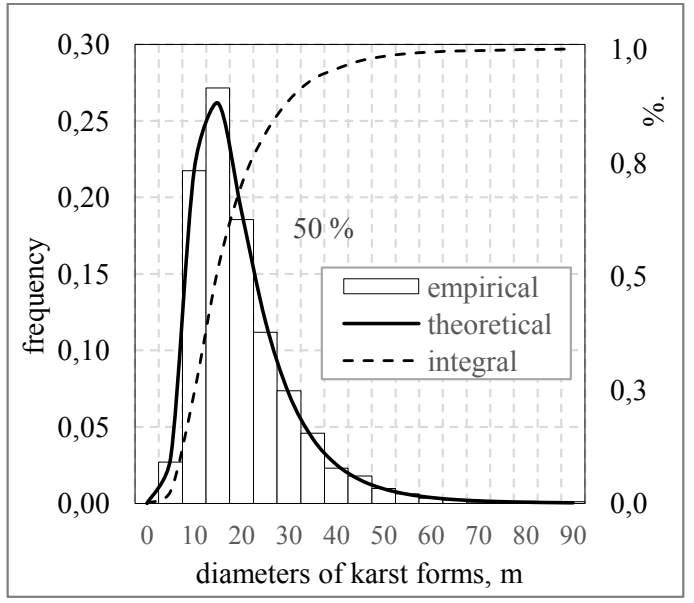

Fig. 5 Histogram of distribution of diameters of karst forms 
Testing the hypothesis is based on the fulfillment of conditions (1-2), with the known assumption that the distribution of the logarithm of the diameters of karst forms obeys the normal law [8]:

$$
\begin{gathered}
|A / \delta a|=<3 \\
|E / \delta e|<3 \\
|A / \delta a|=|-0.005 / 0.029|=0.16 \\
|E / \delta e|=|0.004 / 0.057|=0.67
\end{gathered}
$$

where, Ek - kurtosis, As - asymmetry, $\delta$ e and $\delta$ a standard deviations of skewness and kurtosis estimates, calculated using the built-in Microsoft Office Excel analysis package.

In the Nizhneirensko-Orda area, craters and sinkholes with a transverse size of 10-15 m prevail, the total number of which is $50 \%$ of the total, and the average diameter reaches $17.5 \mathrm{~m}$ (Fig. 5)

Mathematical assessment of the influence of natural factors on the intensity of the formation of karst forms.

1. The main trends in the development of karst associated with the morphological features of the relief (surface or elevation above the drainage level, slope and energy) are integral indicators of erosional dissection and control the distribution of surface runoff and the depth of drainage of karst waters. The regularity of changes in the surface karst content with an increase in the relief surface is clearly visible. In the interval of heights of 128-190 m, advising the slopes of river valleys, the number of forms increases, but when the height exceeds $190 \mathrm{~m}$, their number gradually decreases. A similar trend can be traced for the slopes of the relief. The growth in the value of the energy potential reflects a steady tendency towards an increase in forms. The role of the slope exposure, which determines the nature and intensity of snow melting in the spring, is also indicative, since the maximum karst content is manifested on the slopes of the western and southern exposures, and the minimum for the eastern (Table 1).

2. Geological factors that reflect the features of the geological structure of the research area can be divided into two groups: the thickness of geological divisions and the depth of their roof.

As the depth of occurrence of lithological and Conclusions. The performed analysis of spatial data allowed us to obtain actual quantitative characteristics of the surface karst phenomena, patterns of occurrence and placement of forms in the plan and section, to identify and mathematically justify the main natural and geological conditions for the development of the karst of the Nizhneirensky-Orda area. The prepared materials will form the basis for zoning the territory according to the conditions of karst development and correspond to the pre-project stage of engineering and geological research.

stratigraphic elements increases, the thicknesses lose their role and influence on the surface karst formation. The dominant role belongs mainly to the upper (Tyuiskaya and Demidkovskaya) members of the Irenian horizon, for which a similar tendency is revealed - with increasing thickness, an increase in the number of karst content is observed.

For the uppermost and most destroyed member - Lunezhskaya, the trend is similar, but the strength of the factor is minimal (Table 1).

The second, in its own way, values are indicators of the thickness of the Filippovsky horizon and loose cover deposits. In both cases, an increase in the thickness of deposits is accompanied by a decrease in the number of forms.

3. The indices of the depths of the top of karst deposits have higher coefficients than the geological factors of the first group. With an increase in the depths of the beds of the Irene horizon, their strength and degree of influence decrease. The maximum Emah / E indices belong to the depth factors of the top of the Irenian horizon and the Artinskian stage. With diving below certain marks, the overall karst content decreases (Table 1).

Table 1. Summary of coefficients EMax / E

\begin{tabular}{|l|c|}
\hline \multicolumn{1}{|c|}{ Factor } & $\mathrm{E}_{\mathrm{Max}} / \mathrm{E}$ \\
\hline Relief surface & $\mathbf{1 , 0 9 8 2}$ \\
\hline Terrain slopes & 1,0118 \\
\hline Slope exposure & 1,0131 \\
\hline Relief energy & 1,0270 \\
\hline \multicolumn{2}{|c|}{ Capacities } \\
\hline \multicolumn{2}{|c|}{} \\
\hline Irene horizon & 1,0399 \\
\hline Filippovsky horizon & $\mathbf{1 , 0 6 7 7}$ \\
\hline Lunezhskaya pack & 1,0442 \\
\hline Tuy pack & $\mathbf{1 , 0 8 4 9}$ \\
\hline Demidkovskaya pack & $\mathbf{1 , 0 8 8 6}$ \\
\hline Elkinsky pack & 1,0229 \\
\hline Shalashninskaya pack & 1,0493 \\
\hline Covering deposits & $\mathbf{0 , 0 5 6 5}$ \\
\hline \multicolumn{2}{|c|}{} \\
\hline Irene horizon & $\mathbf{1 , 1 4 8 7}$ \\
\hline Filippovsky horizon & 1,0858 \\
\hline Lunezhskaya pack & $\mathbf{1 , 1 5 4 3}$ \\
\hline Tuy pack & $\mathbf{1 , 1 4 6 9}$ \\
\hline
\end{tabular}




\begin{tabular}{|l|l|}
\hline Demidkovskaya pack & $\mathbf{1 , 1 2 1 5}$ \\
\hline Elkinsky pack & 1,0705 \\
\hline Shalashninskaya pack & 1,0227 \\
\hline Artinskiy tier & $\mathbf{1 , 1 7 6 2}$ \\
\hline
\end{tabular}

The mathematical tendency for the depth of the Filippovian horizon is identical to the Artinskian stage, but the strength of its influence is much less.

\section{Mathematical assessment of the nature and degree of influence of natural factors on the transverse dimensions of surface forms.}

The assessment and justification of the choice of natural factors that have an impact on the size of karst forms is based on testing the hypothesis about the homogeneity of the samples of the diameters of the factor signs among themselves, for their belonging to the same general population. If all samples of a factor belong to the same general population, then we can assume that this factor has practically no effect on the size. For verification, the KomogorovSmirnov criterion was used [8], which showed that all the factors used in the work (Table 1) are capable of influencing the size of karst forms, which in principle is consistent with their distribution law.

The mathematical assessment of determining the degree of significance of the factors under consideration by the strength of their influence on the size of the shape was calculated using the coefficient of mutual conjugation of Chuprov (T) [8]. This paper presents the results of the analysis only for the most significant factors in Table. 1, including the thickness of the overburden (Table 2):

Table 2. Summary table of the values of the contingency coefficient $T$

\begin{tabular}{|l|l|}
\hline \multicolumn{1}{|c|}{ Factor } & $\mathrm{T}$ \\
\hline \multicolumn{2}{|c|}{ Capacities } \\
\hline Lunezhskaya pack & 0,0482 \\
\hline Covering deposits & 0,0560 \\
\hline Relief surface & 0,0695 \\
\hline \multicolumn{2}{|c|}{ Roof depth } \\
\hline Irene horizon & 0,0653 \\
\hline Tuy pack & 0,0596 \\
\hline Demidkovskaya pack & 0,0594 \\
\hline Artinskiy tier & 0,0570 \\
\hline
\end{tabular}

Conclusions. The performed analysis of spatial data allowed us to obtain actual quantitative characteristics of the surface karst phenomena, patterns of occurrence and placement of forms in the plan and section, to identify and mathematically justify the main natural and geological conditions for the development of the karst of the Nizhneirensky-Orda area. The prepared materials will form the basis for zoning the territory according to the conditions of karst development and correspond to the pre-project stage of engineering and geological research.

\section{List of references}

1. SP 11-105-97 Engineering and geological surveys for construction. Part I. General rules of work. Russia (1998).

2. K.A. Gorbunova, V.N. Andreychuk, V.P Kostarev, N.G. Maksimovich. Karst and caves of the Perm region. Publishing house Perm. University, Russia (1992).

3. E.A. Erofeev, V.N. Kataev. Identification of surface karst forms based on satellite images. Geology and minerals of the Western Urals: collection of articles of the 37th All-Russian scientific and practical conference. May 2324 2017, Perm, Perm University, Russia (2017).

4. E.A. Erofeev, V.N. Kataev. Estimative karst interpretation of satellite images of the south - south-eastern districts of Perm region. International Symposium KARST 2018 - Expect the Unexpected. Trebinje, Bosnia and Herzegovina (2018).

5. E.A. Erofeev, V.N. Kataev. Methodical approach to carrying out an estimated karstological interpretation of the territory of karst regions of the Perm Territory. Regional problems of remote sensing of the Earth. Materials of the VI International Scientific Conference. Krasnoyarsk, September 10-13, 2019. Russia (2019).

6. V.V. Tolmachev, G.M. Troitskiy, V.P. Khomenko. Engineering and construction development of karst territories. Stroyizdat, Russia (1986).

7. E.A. Erofeev, V.N. Kataev. Application of probabilistic and statistical methods for assessing karst hazard under conditions of anthropogenic impact on karst territories. Engineering geology. December 4/2010. from 34-46. Russia (2010).

8. I.P. Sharapov. Application of mathematical methods in geology. Publishing house "Nedra", Russia (1971). 